\title{
Isolation and Structural Elucidation of Three New Acetylenic Carotenoids from the Japanese Sea Mussel Mytilus coruscus ${ }^{* 1,2}$
}

\author{
Takashi Maoka*3 and Takao Matsuno*8 \\ (Received February 18, 1988)
}

\begin{abstract}
Three new acetylenic carotenoids, pectenol $\mathbf{B}\left[=\left(3 \mathrm{~S}, 4 \mathrm{~S}, 3^{\prime} \mathrm{R}\right)-7^{\prime}, 8^{\prime}\right.$-didehydro- $\beta, \beta$-carotene- 3,4 , $3^{\prime}$-triol], (3S,4R,3'R)-4-hydroxy-alloxanthin and (3S,4S,3'R)-4-hydroxy-alloxanthin have been isolated from the Japanese sea mussel Mytilus coruscus.
\end{abstract}

In the course of our comparative biochemical studies of carotenoids in shellfishes, we have reported the isolation and structural determination of pectenol, (3S,4R,3'R)-7', $\mathbf{8}^{\prime}$-didehydro- $\beta, \beta$ carotene-3,4,3'-triol, from the Japanese sea mussel Mytilus coruscus. ${ }^{1-3)}$ Recently, we have isolated three new carotenoids from the same species and elucidated by spectral and chemical methods their structures to be $\left(3 \mathrm{~S}, 4 \mathrm{~S}, 3^{\prime} \mathrm{R}\right)-7^{\prime}, 8^{\prime}$-didehydro- $\beta, \beta$ carotene-3,4,3'-triol, (3S,4R, $\left.3^{\prime} \mathrm{R}\right)-7,8,7^{\prime}, 8^{\prime}$-tetradehydro- $\beta, \beta$-carotene- $3,4,3^{\prime}$-triol and $\left(3 \mathrm{~S}, 4 \mathrm{~S}, 3^{\prime} \mathrm{R}\right)-7$, $8,7^{\prime}, 8^{\prime}$-tetradehydro- $\beta, \beta$-carotene- $3,4,3^{\prime}$-triol. The first carotenoid was a stereoisomer of pectenol; thus the former was named pectenol $\mathrm{B}$ and the latter pectenol $\mathrm{A}$.

In this paper we describe the isolation and structural elucidation of these three new carotenoids from $M$. coruscus.

\section{Experimentals}

General

Visible light absorption spectra (VIS) were measured with a Shimadzu UV 240 spectrometer in ether. Concentrations were calculated using $\mathrm{E}_{1 \mathrm{~cm}}^{1 \%}=2500$ at $\lambda \mathrm{max}$. Infrared spectra (IR) were recorded on a Shimadzu IR-27 G spectrophotometer in $\mathrm{KBr}$ pellet. ${ }^{1} \mathrm{H}-\mathrm{NMR}$ spectra were measured in $\mathrm{CDCl}_{3}$ on a Varian XL-300 spectrometer with a tetramethylsilane as an internal standard. MS spectra were recorded with a Hitachi M-80 mass spectrometer with a direct inlet system at $70 \mathrm{eV}, 190-210^{\circ} \mathrm{C}$. Circular dichroism spectra $(\mathrm{CD})$ were measured on a Jasco
J-500 C spectropolarimeter in ether-isopentaneEtOH (5:5:2) (EPA) solution at $20^{\circ} \mathrm{C}$. HPLC was carried out on a Shimadzu LC-6A instrument equipped with a Shimadzu SPD-6VA UV-VIS spectrophotometric detector set at $450 \mathrm{~nm}$.

\section{Extraction and Isolation of Carotenoids}

$M$. coruscus (60 specimens, $40 \mathrm{~kg}$ wet weight) was collected at the Ise Bay, Toba city, Japan.

According to the method previously described, ${ }^{2)}$ the muscles $(6 \mathrm{~kg})$ were extracted with acetone three times. After transferring to ether- $n$-hexane $(1: 1)$ by addition of water, the carotenoids were concentrated under reduced pressure in $\mathbf{N}_{2}$ below $40^{\circ} \mathrm{C}$. The crude carotenoids were separated by preparative thin-layer chromatography (P-TLC) on silica gel $G$ using acetone- $n$-hexane $(3: 7)$. Each band was submitted to further purification by preparative high performance liquid chromatography on a chiral resolution column Sumipax OA-2000 (particle size $5 \mu \mathrm{m}, 300 \times 8 \mathrm{~mm}$ ). ${ }^{4)}$

\section{Derivatization}

Acetylation, trimethylsilylation, allylic $\mathbf{O H}$ test and reduction with $\mathrm{NaBH}_{4}$ were carried out by our routine procedures. ${ }^{2,5)}$

\section{Pectenol B (Yield $2.0 \mathrm{mg}$ ) \\ M.p. ${ }^{184}-185^{\circ} \mathrm{C}$ (from $n$-hexane-ether), VIS, $\lambda \max$ (ether) 425,451 and $479 \mathrm{~nm} ; \mathrm{MS}, \mathrm{m} / \mathrm{z}$ $582.4055\left(\mathrm{M}^{+}, \mathrm{C}_{40} \mathrm{H}_{54} \mathrm{O}_{3}, 100 \%\right), 564\left(\mathrm{M}^{+}-18\right.$, $20 \%), 562\left(\mathrm{M}^{+}-20,12 \%\right), 546\left(\mathrm{M}^{+}-18-18,5 \%\right)$, $528\left(\mathrm{M}^{+}-18-18-18,3 \%\right), 490\left(\mathrm{M}^{+}-92,5 \%\right), 476$ $\left(\mathrm{M}^{+}-106,2 \%\right)$; IR, ข $\max 3300(\mathrm{OH}), 2165$}

*1 This work was presented at the 8th International Symposium on Carotenoids, Boston, U. S. A., 27-31 July 1987.

*2 Carotenoids of Shellishes-IX.

*3 Department of Natural Products Research, Kyoto Pharmaceutical University, Misasagi, Yamashina, Kyoto 607, Japan (且同孝至, 松野隆男: 京都薬科大学天然物化学教室). 
(-C $\equiv \mathrm{C}$-), and 960 (trans $-\mathrm{CH}=\mathrm{CH}-$ ); ${ }^{1} \mathrm{H}-\mathrm{NMR}$; (Fig. 2); and CD, $\lambda \max 224(d \varepsilon-9.0), 235(0)$, $246(+6.0), 262(0), 285(-21.5), 310(0)$ and 340 $\mathrm{nm}(+2.0)$.

$\left(3 S, 4 R, 3^{\prime} R\right)-4-H y d r o x y$-alloxanthin (Yield $0.4 \mathrm{mg}$ )

M.p. $180-182^{\circ} \mathrm{C}$ (from $n$-hexane-ether); VIS, $\lambda \max 426,452$ and $480 \mathrm{~nm}$; MS, $\mathrm{m} / \mathrm{z} 580.3912$ $\left(\mathrm{M}^{+}, \mathrm{C}_{40} \mathrm{H}_{52} \mathrm{O}_{3}, 100 \%\right), 562\left(\mathrm{M}^{+}-18,20 \%\right), 544$ $\left(\mathrm{M}^{+}-18-18,6 \%\right), 562\left(\mathrm{M}^{+}-18-18-18,3 \%\right)$ and $488\left(\mathrm{M}^{+}-92,3 \%\right)$; IR, ข $\max 3300(\mathrm{OH}), 2165$ (-C $\equiv \mathrm{C}$-) and 960 (trans $-\mathrm{CH}=\mathrm{CH}-$ ); ${ }^{1} \mathrm{H}-\mathrm{NMR}$, (Fig. 2) and $\mathrm{CD}$; (Fig. 3).

(3S,4S,3'R)-4-Hydroxy-alloxanthin (yield $0.1 \mathrm{mg}$ )

M.p. $175-177^{\circ} \mathrm{C}$ (from $n$-hexane-ether), VIS, $i \max$ (ether) 426,452 and $480 \mathrm{~nm} ; \mathrm{MS}, \mathrm{m} / \mathrm{z}$ $580.3910\left(\mathrm{M}^{+}, \mathrm{C}_{40} \mathrm{H}_{50} \mathrm{O}_{3}, 100 \%\right), 562\left(\mathrm{M}^{+}-18\right.$, $18 \%), 544\left(\mathrm{M}^{+}-18-18,7 \%\right), 562\left(\mathrm{M}^{+}-18-18-18\right.$, $3 \%$ ) and $488\left(\mathrm{M}^{+}-92,2 \%\right)$; IR, $\nu \max 3300(\mathrm{OH})$, $2165\left(-\mathrm{C} \equiv \mathrm{C}_{-}\right.$) and 960 (trans $\left.-\mathrm{CH}=\mathrm{CH}-\right) ;{ }^{1} \mathrm{H}-$ NMR, (Fig. 2) and CD; (Fig. 3).

Alloxanthin (yield $22.0 \mathrm{mg}$ )

VIS $\lambda \max$ (ether) 426,452 and $480 \mathrm{~nm}$; ${ }^{1} \mathrm{H}-$ NMR, (Fig. 2); and CD, (Fig. 3).
(3S, $3^{\prime} R$ )-4-Keto-alloxanthin (yield $0.2 \mathrm{mg}$ )

VIS, $\lambda \max$ (ether) $469 \mathrm{~nm}$; MS, m/z 578.3762 $\left(\mathrm{M}^{+}, \mathrm{C}_{40} \mathrm{H}_{30} \mathrm{O}_{3}, 100 \%\right), 560\left(\mathrm{M}^{+}-18,20 \%\right), 542$ $\left(\mathrm{M}^{+}-18-18,10 \%\right)$ and $486\left(\mathrm{M}^{+}-92,5 \%\right)$; IR, $\nu \max 3300(\mathrm{OH}), 2165 \quad(-\mathrm{C} \equiv \mathrm{C}$ ) $), 1660$ (conj. $>\mathrm{C}=\mathrm{O}$ ) and 960 (trans $-\mathrm{CH}=\mathrm{CH}-$ ) $\mathrm{cm}^{-1}$; ${ }^{\mathrm{H}} \mathrm{H}-$ NMR (Fig. 2); and CD, $\lambda \max 230(\Delta \varepsilon+4.0)$, $240(0), 302(-5.2)$ and $312 \mathrm{~nm}(0)$.

Preparation of $\left(3 S, 4 R, 3^{\prime} R\right)$ - and $\left(3 S, 4 S, 3^{\prime} R\right)-4$ hydroxy-alloxanthin from $\left(3 S, 3^{\prime} R\right)-4-$ keto-alloxanthin

According to the method described previously,,$^{3,8)}$ (3S, $3^{\prime} R$ )-4-keto-alloxanthin was reduced by $\mathrm{NaBH}_{4}$ in $\mathrm{MeOH}$. The separation between stereoisomers of $\left(3 \mathrm{~S}, 4 \mathrm{R}, 3^{\prime} \mathrm{R}\right)$ - and $\left(3 \mathrm{~S}, 4 \mathrm{~S}, 3^{\prime} \mathrm{R}\right)-4$ hydroxy-alloxanthin was carried out by HPLC on Sumipax OA-2000.

\section{Results and Discussion}

Fig. 1 shows the HPLC of triol fraction obtained from $M$. coruscus.

Carotenoid 1 (peak 1 in HPLC, yield $12 \mathrm{mg}$ ) was identified as pectenol $A$ [previously called pectenol $=\left(3 \mathrm{~S}, 4 \mathrm{R}, 3^{\prime} \mathrm{R}\right)-7^{\prime}, 8^{\prime}$-didehydro- $\beta, \beta$ carotene-3,4,3'-triol].

Carotenoid 2 (peak 3 in HPLC, yield $2 \mathrm{mg}$ )

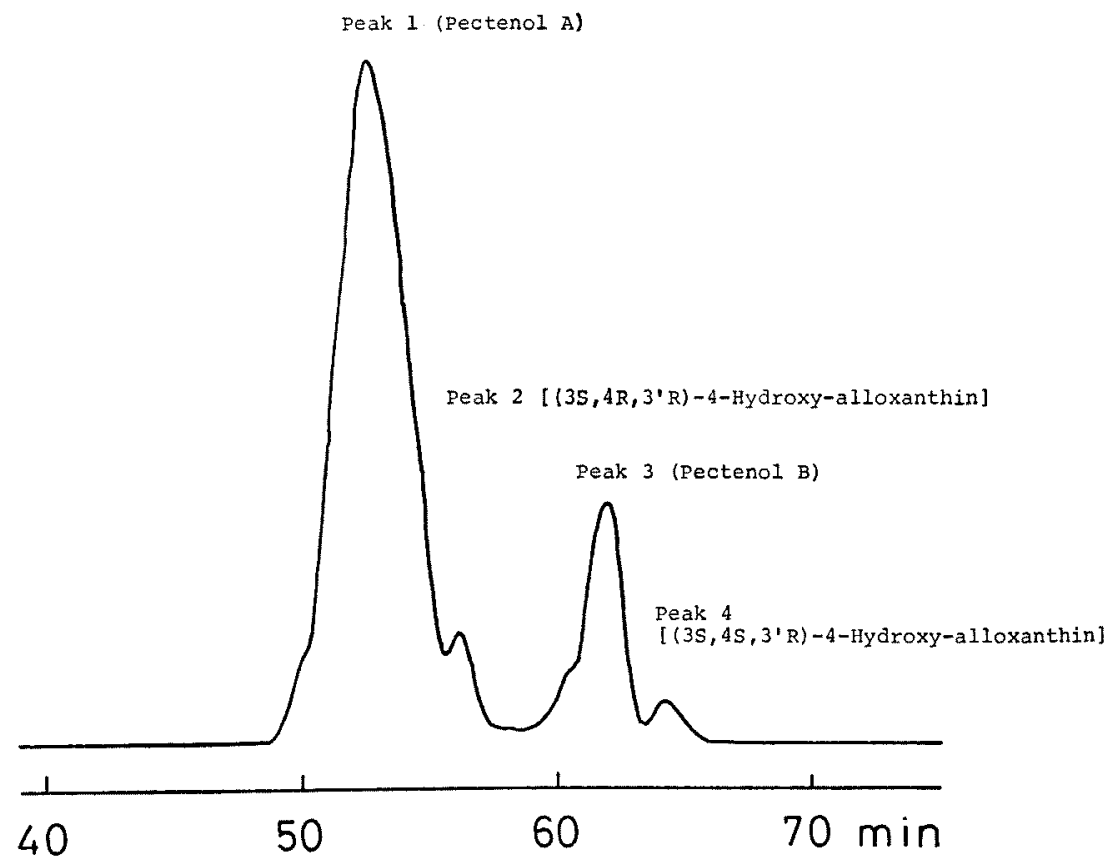

Fig. 1. HPLC of triol fraction obtained from $M$. coruscus. Column, Sumipax OA-2000; Mobile phase, $n$-hexane- $\mathrm{CH}_{2} \mathrm{Cl}_{2}$-EtOH (48: 16:1.5); Flow-rate, $2.0 \mathrm{~m} l / \mathrm{min}$. 

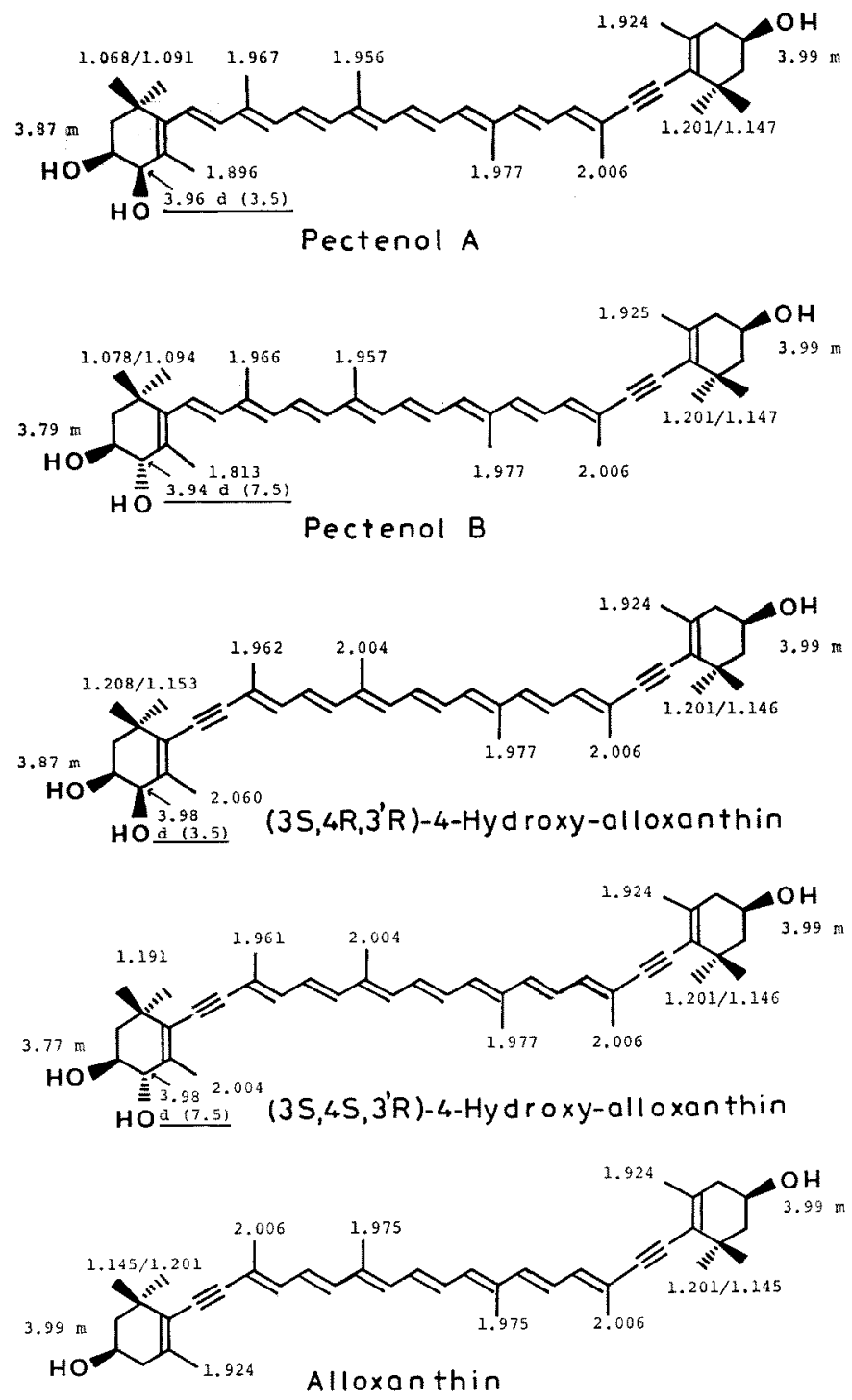

Fig. 2. ${ }^{1} H-N M R$ assignments of pectenol $A$, pectenol $B,\left(3 S, 4 R, 3^{\prime} R\right)-4$-hydroxy-alloxanthin, (3S,4S,3'R)-4-hydroxy-alloxanthin and alloxanthin.

was obtained as reddish needles (m.p. $184-185^{\circ} \mathrm{C}$ ), and showed the same VIS, MS $\left(\mathrm{M}^{+}, \mathrm{m} / \mathrm{z} 582.4055\right.$, $\mathrm{C}_{40} \mathrm{H}_{54} \mathrm{O}_{3}$ ), IR, ${ }^{1} \mathrm{H}-\mathrm{NMR}$ (Fig. 2) and $\mathrm{CD}$ spectra (Fig. 3) as those of semisynthetic (3S,4S,3'R)-7', 8 '-didehydro- $\beta, \beta$-carotene-3,4,3'-triol prepared by $\mathrm{NaBH}_{4}$ reduction of pectenolone. ${ }^{3,6)}$ Furthermore, 2 was indistinguishable from the semisynthetic (3S, 4S, 3'R)- $7^{\prime}, 8^{\prime}$-didehydro- $\beta, \beta$-carotene- $3,4,3^{\prime}$ triol in HPLC on various columns. Thus, the structure of pectenol $B$ was established to be $\left(3 \mathrm{~S}, 4 \mathrm{~S}, 3^{\prime} \mathrm{R}\right)-7^{\prime}, 8^{\prime}$-didehydro- $\beta, \beta$-carotene- $3,4,3^{\prime}$ triol.
Carotenoid 3 (peak 2 in HPLC, yield $0.4 \mathrm{mg}$ ) was obtained as reddish needles (m.p. $180-182^{\circ} \mathrm{C}$ ), and showed $\lambda \max (426), 452$ and $480 \mathrm{~nm}$. IR absorption band at $\nu \max 2165 \mathrm{~cm}^{-1}$ revealed the presence of a disubstituted acetylene group in 3 . The molecular formula of $\mathbf{3}$ was determined to be $\mathrm{C}_{40} \mathrm{H}_{52} \mathrm{O}_{3}$ by high-resolution EIMS measurement $\left(\mathrm{M}^{+}, \mathrm{m} / \mathrm{z} 580.3912 \Delta 0.0001\right)$. The presence of three hydroxy groups (primary or secondary) was consistent with the formation of a triacetate and tri-trimethylsilyl ether. And one of the hydroxy groups was proved to be allylic by allylic $\mathrm{OH}$ 


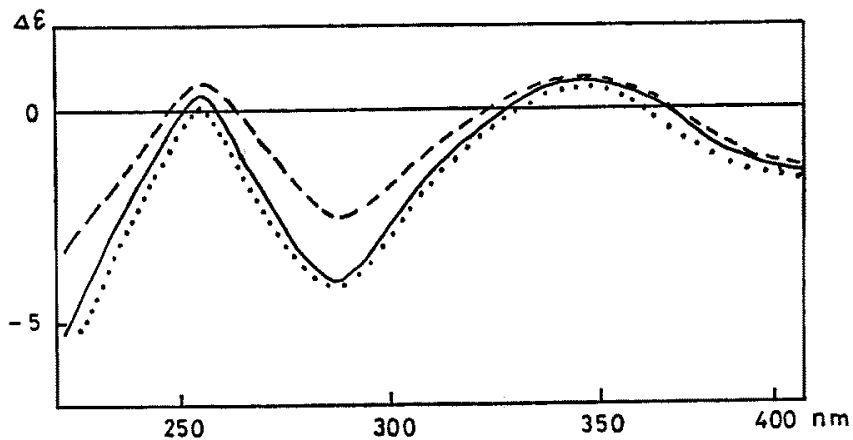

Fig. 3. $C D$ spectra of ( $\left.3 S, 4 R, 3^{\prime} R\right)-4$-hydroxy-alloxanthin, - (3S, $\left.4 S, 3^{\prime} R\right)$-4-hydroxy-alloxanthin - - and alloxanthin ... in EPA at $20^{\circ} \mathrm{C}$.
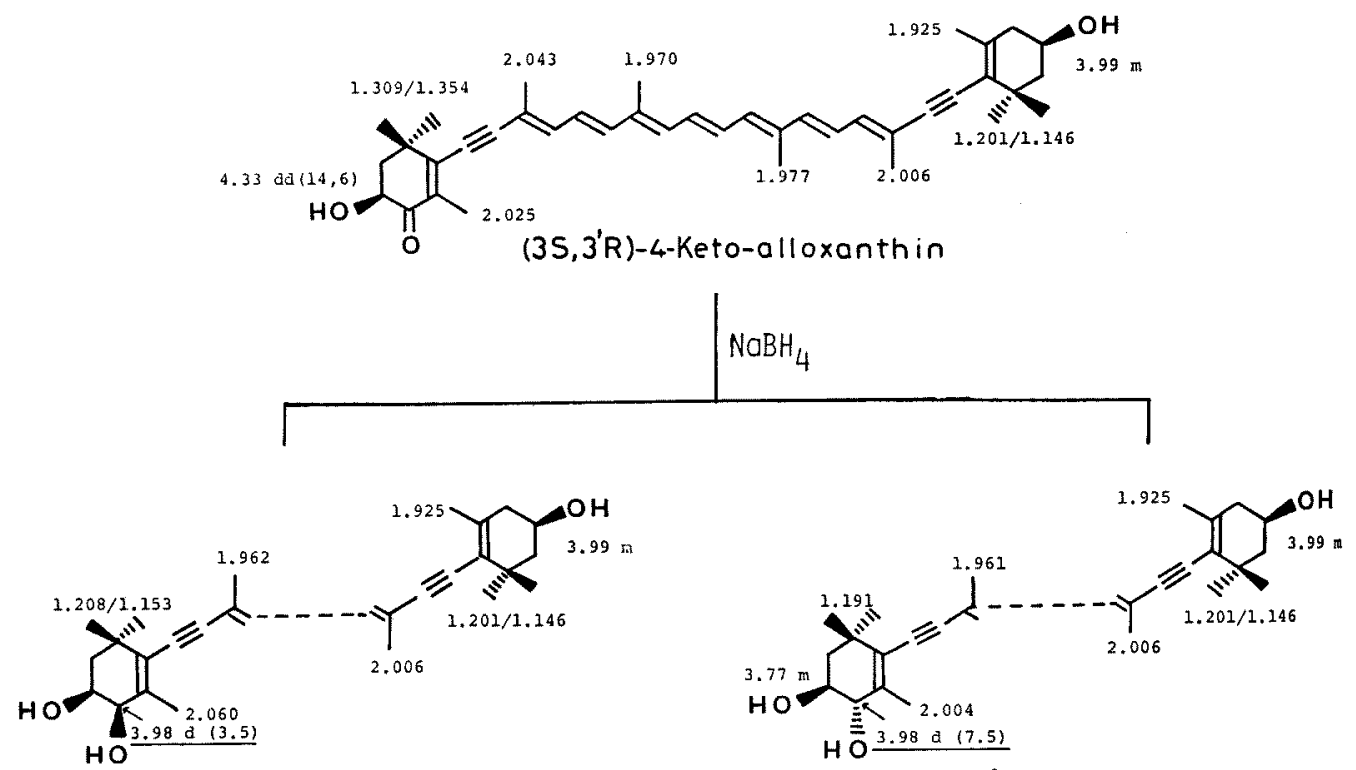

(3S, 4R, $3^{\prime} R$ )-4-Hyd roxy-alloxanthin

$\left(3 S, 4 S, 3^{\prime} R\right)-4-H y d$ roxy-alloxanthin

Fig. 4. Preparation of (3S,4R,3'R)-4-hydroxy-alloxanthin and (3S,4S,3'R)-4-hydroxy-alloxanthin

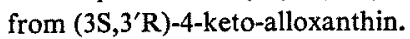

test. ${ }^{1} \mathrm{H}-\mathrm{NMR}$ spectral assignments (Fig. 2) for 3 were consistent with a moiety of alloxanthin molecule. Furthermore, the methine proton at $\delta 3.98(\mathrm{~d}, \mathrm{~J}=3.5 \mathrm{~Hz}$ ) showed the presence of a 3,4(cis)-dihydroxy- $\beta$-end group ${ }^{7)}$ in the molecule of 3. On the basis of the evidences described above, we assigned $3,4-(\mathrm{cis})-7,8,7^{\prime}, 8^{\prime}$-tetradehydro- $\beta, \beta$ carotene-3,4,3'-triol for the structure of carotenoid 3. The CD spectrum (Fig. 3) of 3 was superimposable on that of alloxanthin. It is well known that an additional hydroxy substituent in the allylic 4-position in $\beta$-end group has no marked influence on the $C D$ spectrum. ${ }^{8, \theta)}$, Therefore it was assumed that 3 has the same chiralities at $\mathrm{C}-3$ and $\mathrm{C}-3^{\prime}$ as those of alloxanthin. Thus the structure of carotenoid 3 has been tentatively postulated to be $\left(3 S, 4 R, 3^{\prime} R\right)-4$-hydroxy-alloxanthin $[=(3 S$, $\left.4 \mathrm{R}, 3^{\prime} \mathrm{R}\right)-7,8,7^{\prime}, 8^{\prime}$-tetradehydro- $\beta, \beta$-carotene- $3,4,3^{\prime}$ triol].

In order to confirm the validity of the proposed structure of carotenoid $3,\left(3 S, 4 R, 3^{\prime} R\right)$-4-hydroxyalloxanthin was prepared by $\mathrm{NaBH}_{4}$ reduction of (3S,3'R)-4-keto-alloxanthin isolated from $M$. coruscus (Fig. 4). As was expected, carotenoid 3 was proved to be completely identical with the semisynthetic (3S,4R,3'R)-4-hydroxy-alloxanthin by the comparison of physico-chemical data described above. Therefore the structure of 
carotenoid 3 was determined to be $\left(3 \mathrm{~S}, 4 \mathrm{R}, 3^{\prime} \mathrm{R}\right)-7$, $8,7^{\prime}, 8^{\prime}$-tetradehydro- $\beta, \beta$-carotene- $3,4,3^{\prime}$-triol.

Carotenoid 4 (peak 4 in HPLC, yield $0.1 \mathrm{mg}$ ) was isolated as reddish needles (m.p. $175-177^{\circ} \mathrm{C}$ ). The VIS, MS $\left[\mathrm{M}^{+}, \mathrm{m} / \mathrm{z} 580.3910, \mathrm{C}_{40} \mathrm{H}_{82} \mathrm{O}_{3}\right.$, IR and $C D$ (Fig. 3) spectral data of 4 were almost identical with those of $\left(3 S, 4 S, 3^{\prime} R\right)$-4-hydroxyalloxanthin. This carotenoid also provided a triacetate, a tri-trimethylsilyl ether and a monomethyl ether by acetylation, trimethyl silylation and allylic $\mathrm{OH}$ test, respectively. Furthermore, the ${ }^{1}$ H-NMR spectral data (Fig. 2) of $\mathbf{4}$ showed the presence of a moiety of alloxanthin molecule. On the other hand, methin proton at $\delta 3.98$ (d, $\mathrm{J}=7.5 \mathrm{~Hz}$ ) indicated the presence of a 3,4-(trans)dihydroxy- $\beta$-end group ${ }^{7}$ in the molecule of 4 . Therefore we assumed that this carotenoid is a 4-epimer of $\left(3 S, 4 R, 3^{\prime} R\right)$-4-hydroxy-alloxanthin, namely, (3S, 4S,4'R)-4-hydroxy-alloxanthin.

Similarly, we prepared semisynthetic $(3 S, 4 S$, $3^{\prime} R$ )-4-hydroxy-alloxanthin from (3S,3'R)-4-ketoalloxanthin by $\mathrm{NaBH}_{4}$ reduction, and directly compared it with carotenoid 4. Expectedly 4 has been proved to be completely coincided with semisynthetic (3S,4S,3'R)-4-hydroxy-alloxanthin by comparison with physico-chemical data described previously. Therefore the structure of carotenoid 4 was determined to be $\left(3 S, 4 S, 3^{\prime} R\right)-4-$ hydroxy-alloxanthin $\left[=\left(3 \mathrm{~S}, 4 \mathrm{~S}, 3^{\prime} \mathrm{R}\right)-7,8^{\prime}, 7^{\prime}, 8^{\prime}\right.$-tetradehydro- $\beta, \beta$-carotene- $3,4,3^{\prime}$-triol].
In conclusion, we isolated four new acetylenic carotenoids, pectenol A, pectenol $B,\left(3 S, 4 R, 3^{\prime} R\right)$ 4-hydroxy-alloxanthin and (3S,4S, $\left.3^{\prime} R\right)$-4-hydroxyalloxanthin from $M$. coruscus. These acetylenic carotenoids are assumed to be derived from diatoxanthin and alloxanthin originating from microalgae which mussels prey on.

\section{References}

1) T. Matsuno, T. Maoka, and K. Hiraoka: Nippon Suisan Gakkaishi, 47, 143 (1981).

2) T. Matsuno and T. Maoka: Nippon Suisan Gakkaishi, 47, 377-384 (1981).

3) T. Matsuno, T. Maoka, S. Sakaguchi, and T. Nishizawa: Nippon Suisan Gakkaishi, 50, 12511253 (1984).

4) T. Maoka, T. Komori, and T. Matsuno: $J$. Chromatogr., 318, 122-124 (1985).

5) T. Matsuno, M. Katsuyama, T. Maoka, T. Hirono, and T. Komori: Comp. Biochem. Physiol., 80B, 779-789 (1985).

6) T. Matsuno, K. Hiraoka, and T. Maoka: Nippon Suisan Gakkaishi, 47, 501-505 (1981).

7) G. Englert: in "Carotenoid Chemistry and Biochemistry" (ed. by G. Britton and T.W. Goodwin), Pergamon Press, Oxford, 1982, p. 111.

8) R. Buchecker and S. Liaaen-Jensen: Phytochemistry, 16, 729-733 (1977).

9) S. Liaaen-Jensen: Fortschritte Chem. Org. Naturstoffe, 39, 122-127 (1980). 